\title{
Comments on "The burden of avoidable disease from air pollution: implications for prevention"
}

\author{
Wojciech Hanke' ${ }^{1}$ Witold A. Zatoński² \\ 'Department of Environmental Epidemiology, Nofer Institute of Occupational Medicine, Łódź, Poland \\ ${ }^{2}$ Institute - European Observatory of Health Inequalities, Calisia University, Kalisz, Poland
}

ADDRESS FOR CORRESPONDENCE: Wojciech Hanke, Department of Environmental Epidemiology, Nofer Institute of Occupatinal Medicine, 8 Św. Teresy od Dzieciątka Jezus St., 91-348 Łódź, Poland, e-mail: Wojciech.Hanke@imp.lodz.pl

The COVID-19 pandemic poses a major challenge for public health care. However, it is by no means the only epidemic we are faced with. Most developed countries, including Poland, have struggled for decades with several major health problems, the management of which requires continuous efforts. Already before the onset of the coronavirus pandemic, Poland was a country with one of the lowest life expectancies in the European Union (it was the sixth worst performing country). In the last decades Poland's position declined by two positions. Poland's poor performance is the result of a triad of risk factors that shape the population health in the country tobacco use, alcohol use, and air pollution [1-5].

The editors of the Journal of Health Inequalities, together with the scientific community centred around Calisia University several other institutions in Poland, chose environmental pollution as one of the key topics of the public health conference that was held in June 2019 in Kalisz (Calisia World Conference on Family Health, 9-10 June 2019) [6].

The authors of the present issue of the Journal of Health Inequalities direct our attention to the health burden resulting from air pollution and toxins from other sources which humans inhale. The authors show that ambient air pollution and cigarette smoking remain two major contributions to disease burden in Poland, despite the substantial improvements in tobacco control and improvements in air quality over the last years. Jonathan Samet (Dean of the Colorado School of Public Health, who participated in Calisia World Conference on Family Health), Meghan Buran and Mark Parascandola (in the Tobacco Control Research Branch, Division of Cancer Control and Population Sciences, at the National Cancer Institute, Bethesda, USA) argue that sustained public health efforts are needed to effectively control both air pollution and smoking-related diseases [7, 8]. As we face new health challenges, such as COVID-19 pandemic, the efforts should be even stronger.

Jonathan Samet and Meghan Buran provide estimates of the burden of both these epidemics and indicate the key areas for their control [8]. In Poland, the scientific community has been warning about the impact on health of both air pollution and smoking in the recent years, and especially the multiplicative effect of these risk factors. However, there have only been limited attempts at systematically describing the magnitude and direction of these interrelated problems, and the estimates of their burden provided by the authors is a much-needed starting point.

Professor Witold Zatoński and I would like this to also constitute a starting point for a vibrant scientific discussion about this problem in Poland, which is still not properly understood, described and estimated. Voices in the mass media speculating about the number of air pollution deaths in Poland (with figures cited varying from 40 , through 60 , to 80 thousand), are less important in precipitating adequate solutions than rigorous training that would allow scientists, politicians, and the public to understand how important is the problem of the health impact of pollution, for example on cardiovascular diseases (which are the biggest group of diseases caused by air pollution, a fact which few members of the public have been taught to appreciate).

We would therefore like to invite all the experts in the scientific community interested in such knowledge exchange activity to contribute their views, data, and analysis to the Journal of Health Inequalities, also in the form of short contributions. We hope that the discussion initiated by the paper of Jonathan Samet and Meghan Buran in will trigger not only a reflection about the pres- 
ent impact of air pollution and smoking on health, but will also provide a much-needed impulse for action.

\section{DISCLOSURE}

The authors report no conflict of interest.

\section{References}

1. Zatoński WA. One hundred years of health in Poland. J Health Inequal 2019; 5 (1): 11-19.

2. McMichael A, Zatoński W. Environmental, behavioral, and socioeconomic influences: tackling the historical jigsaw puzzle of health in Central and Eastern Europe. Int J Occup Environ Health 1996; 2 (2): 161-163.

3. McKee M, Zatoński W. How the cardiovascular burden of illness is changing in eastern Europe. Evid Based Cardiovasc Med 1998; 2 (2): 39-41.

4. Apel przedstawicieli sektora zdrowia dotyczący działań na rzecz zdrowia w obliczu zmiany klimatu. Available from: https://lekarzedlaklimatu.pl/ (accessed: 14 December 2020).

5. Binczyk E. Controversies that have been fabricated. From tobacco smoke to global warming. J Health Inequal 2016; 2 (2): 133-134.

6. Janik-Koncewicz K. Report from the Calisia World Conference on Family Health, Kalisz, Poland, 9-10 June 2019. J Health Inequal 2019; 5 (1): 2-10

7. Parascandola M. Ambient air pollution and lung cancer in Poland: research findings and gaps. J Health Inequal 2018; 4 (1): 3-8.

8. Samet J, Buran M. The burden of avoidable disease from air pollution: implications for prevention. J Health Inequal 2020; $6(1): 2-6$.

\section{AUTHORS' CONTRIBUTIONS}

WH and WZ prepared the concept and the final version of the article. 